\title{
THE IMPORTANCE OF ATTITUDES IN STATISTICS EDUCATION
}

\author{
CAROLINE RAMIREZ \\ University of the Pacific \\ caaramirez@aol.com \\ CANDACE SCHAU \\ CS Consultants, $L L C$ \\ Professor Emerita, University of New Mexico \\ cschau@comcast.net \\ ESMA EMMIOĞLU \\ Gaziosmanpasa University \\ esma.Emmioglu@gmail.com
}

\begin{abstract}
People forget what they do not use. But attitudes "stick." Our article emphasizes the importance of students' attitudes toward statistics. We examine 15 surveys that purport to assess these attitudes and then describe the Survey of Attitudes Toward Statistics, a commonly used attitude survey. We present our conceptual model of Students' Attitudes Toward Statistics (SATS-M), which is congruent with Eccles and colleagues' Expectancy-Value Theory (Eccles' EVT), as well as others. The SATS-M includes three broad constructs that impact Statistics Course Outcomes: Student Characteristics, Previous Achievement-Related Experiences, and Statistics Attitudes. We briefly describe Eccles' EVT and other theories that support our SATS-M. We relate findings from research using the SATS to our model and end with implications for statistics education.
\end{abstract}

Keywords: Statistics education research; Students' attitudes toward statistics; SATS-36; Expectancy-value theory

\section{INTRODUCTION}

An ultimate goal of statistics education is to produce statistically literate adults who appropriately use statistical thinking. Statistics is the only discipline where it is perhaps accepted and expected that students can learn what they need in one introductory course. This introductory course, then, is where we, as statistics instructors, do or do not motivate students to learn the statistical skills that they will need in their professional and personal lives. However, being statistically literate means more than learning skills. Students need to recognize when they should apply statistical thinking, accurately use the skills they possess, know when they require additional statistical knowledge and skills, and obtain this additional statistical understanding. During their introductory statistics course, students need to

- believe that they can understand and use statistics,

- think that statistics is useful both in their professional and personal lives,

- recognize that statistics can be interesting,

- be willing to invest the effort needed to learn statistical thinking and skills, and,

- realize that statistics is not easy but it also is not too difficult to learn.

These statements describe attitudes about statistics, the "other" important outcome in statistics education (Garfield, Hogg, Schau, \& Whittinghill, 2002; Schau, 2003b).

The National Council of Teachers of Mathematics has recommended that teachers attend to and assess students' attitudes as part of mathematics instruction (NCTM, 1989, 1991). Attitudes have emerged as primary factors in understanding students' mathematics achievement, their mathematics

Statistics Education Research Journal, 11(2), 57-71, http://www.stat.auckland.ac.nz/serj

C International Association for Statistical Education (IASE/ISI), November, 2012 
ability beliefs, and their expectations for success in mathematics (Wigfield \& Eccles, 2000). Despite this acknowledgement in mathematics education, the same degree of recognition has not yet occurred in statistics education.

Considering that statistics coursework is perhaps the major contributor to a statistically literate society, students' attitudes toward statistics deserve special attention. To assist in this endeavor, we developed a broad conceptual model of students' attitudes toward statistics. To create this model, we first reviewed a large body of literature in statistics education and educational psychology. This review demonstrated that students' attitudes have been included in many theories and empirical studies in disciplines other than statistics education to help explain students' achievement-related choices.

We emphasize the importance of students' attitudes toward statistics throughout our article. We begin by presenting a selection of surveys that purport to assess these attitudes, highlighting the Survey of Attitudes Toward Statistics (SATS-28 and SATS-36; Schau, 1992, 2003a). We then present our conceptual model of Students' Attitudes Toward Statistics (SATS-M), which is based on Eccles and colleagues' Expectancy-Value Theory (Eccles' EVT) as well as other educational theories. The SATS-M consists of three broad constructs that impact Statistics Course Outcomes: Student Characteristics, Previous Achievement-Related Experiences, and Statistics Attitudes. We briefly describe Eccles' EVT and provide additional theoretical support for our SATS-M. We then relate findings from research using the SATS to our model and present implications from the SATS-M for statistics education, both for instruction and research.

\section{CONCEPTUALIZATIONS AND MEASURES OF STATISTICS STUDENTS’ ATTITUDES}

The research literature on students' attitudes reflects little consensus about how attitudes are conceptualized; this lack of consensus is evidenced by the substantial variation in the surveys designed to measure these attitudes. Yet, if we want to explore the impacts of students' attitudes toward statistics, we must be able to assess these attitudes and assess them well.

\subsection{SURVEYS ASSESSING STUDENTS’ ATTITUDES TOWARD STATISTICS}

The most frequently used approach to assess students' attitudes toward statistics is a survey containing Likert-type items. Table 1 contains a list of 15 surveys that purport to assess at least some aspects of students' attitudes toward statistics. These surveys were published in journals or presented at major conferences. We did not include instruments that focus on attitudes toward other fields (such as psychology or research). A few of these surveys have been used in many research studies (e.g., the SAS, ATS, SATS-28, and SATS-36); others have been used in a few studies, sometimes only in the one study conducted by the researcher who created the measure. These surveys were developed in several different countries at different times. They contain from 1 to 6 attitude components.

As Table 1 shows, the constructs found in these surveys have a variety of names, although some names and constructs appear to be at least somewhat similar across surveys: anxiety, fear, enjoyment, and affect; self-efficacy, self-concept, confidence, and cognitive competence; value, utility, usefulness, and worth; interest; and effort. In spite of these similarities, the surveys do not present a consistent picture of students' attitudes toward statistics.

Out of these 15 surveys, four of them have been used the most. These are the Statistics Attitude Survey (SAS) by Roberts and Bilderback (1980; see also Roberts and Saxe, 1982), the Attitudes Toward Statistics (ATS) survey by Wise (1985), and the Survey of Attitudes Toward Statistics-28 (SATS-28) and its expanded version, the Survey of Attitudes Toward Statistics-36 (SATS-36).

Beginning in the 1980s, there were two frequently used surveys claiming to assess post-secondary students' attitudes toward statistics: the SAS and the ATS. The creators of these measures essentially originated survey research into students' statistics attitudes.

Roberts and Bilderback (1980) designed the SAS to predict students' achievement in statistics classes. The SAS yields one global attitude score. Despite extensive use of this survey, problems related to the content and the internal component structure of the SAS have been reported. For example, the use of a single attitude score implies that the construct of attitudes toward statistics is 
Table 1. Surveys purporting to assess students’ attitudes toward statistics

\begin{tabular}{|c|c|c|}
\hline $\begin{array}{l}\text { Number of } \\
\text { Constructs }\end{array}$ & Name of Instrument (Citations) & Constructs \\
\hline \multirow[t]{4}{*}{1} & $\begin{array}{l}\text { SAS: Statistics Attitude Survey } \\
\text { (Roberts \& Bilderback, 1980) }\end{array}$ & One global attitude score \\
\hline & $\begin{array}{l}\text { CSSE: Current Statistics Self-efficacy } \\
\text { (Finney \& Schraw, 2003) }\end{array}$ & Current statistics self-efficacy \\
\hline & $\begin{array}{l}\text { SELS: Self-Efficacy to Learn Statistics } \\
\text { (Finney \& Schraw, 2003) }\end{array}$ & Self-efficacy to learn statistics \\
\hline & $\begin{array}{l}\text { STACS: Student Attitudes and } \\
\text { Conceptions in Statistics (Evans, 2007) }\end{array}$ & Statistics attitudes \\
\hline \multirow[t]{2}{*}{2} & $\begin{array}{l}\text { ATS: Attitudes Toward Statistics } \\
\text { (Wise, 1985) }\end{array}$ & $\begin{array}{l}\text { Attitude toward course, attitude toward the } \\
\text { field }\end{array}$ \\
\hline & $\begin{array}{l}\text { SAI: Statistics Anxiety Inventory } \\
\text { (Zeidner, 1991) }\end{array}$ & $\begin{array}{l}\text { Statistics content anxiety, statistics test } \\
\text { anxiety }\end{array}$ \\
\hline 3 & $\begin{array}{l}\text { Quantitative Attitudes (Harlow, } \\
\text { Burkholder, \& Morrow, 2002) }\end{array}$ & $\begin{array}{l}\text { Quantitative self-efficacy, quantitative } \\
\text { anxiety, perceived quantitative hindrances }\end{array}$ \\
\hline \multirow[t]{2}{*}{4} & $\begin{array}{l}\text { Survey of Attitudes Toward Statistics- } \\
28 \text { (Schau, 1992; Schau, Stevens, } \\
\text { Dauphinee, \& Del Vecchio, 1995) }\end{array}$ & $\begin{array}{l}\text { Affect, cognitive competence, value, } \\
\text { difficulty }\end{array}$ \\
\hline & $\begin{array}{l}\text { Students’'Attitudes Toward Statistics } \\
\text { Questionnaire (Bayot, Mondejar, } \\
\text { Mondejar, Monsalve, Vargas, 2005) }\end{array}$ & $\begin{array}{l}\text { Interest, anxiety, present utility, professional } \\
\text { utility }\end{array}$ \\
\hline 5 & $\begin{array}{l}\text { MSATS: Multi-factorial Scale of } \\
\text { Attitudes Toward Statistics (Auzmendi, } \\
\text { 1991) }\end{array}$ & $\begin{array}{l}\text { Motivation, enjoyment, anxiety, confidence, } \\
\text { usefulness }\end{array}$ \\
\hline \multirow[t]{5}{*}{6} & $\begin{array}{l}\text { STARS: Statistical Anxiety Rating } \\
\text { Scale (Cruise, Cash, \& Bolton, 1985) }\end{array}$ & $\begin{array}{l}\text { Perceived worth of statistics, interpretation } \\
\text { anxiety, test and class anxiety, computation } \\
\text { self-concept, fear of asking for help, and } \\
\text { fear of statistics teachers }\end{array}$ \\
\hline & $\begin{array}{l}\text { Unnamed Instrument (Zanakis \& } \\
\text { Valenzi, 1997) }\end{array}$ & $\begin{array}{l}\text { Student interest in and perceived worth of } \\
\text { statistics, anxiety when seeking help for } \\
\text { interpretation, computer usefulness and } \\
\text { experience, math anxiety, understanding } \\
\text { anxiety, test anxiety }\end{array}$ \\
\hline & $\begin{array}{l}\text { STSQ: Self-efficacy Toward Statistics } \\
\text { Questionnaire (Lane, Hall, \& Lane, } \\
\text { 2002) }\end{array}$ & $\begin{array}{l}\text { Using information technology, motivated } \\
\text { behavior, time management, statistical } \\
\text { theory, general competencies theme, lecture } \\
\text { behavior }\end{array}$ \\
\hline & $\begin{array}{l}\text { SATS-36: Survey of Attitudes Toward } \\
\text { Statistics-36 (Schau, 2003a, b) }\end{array}$ & $\begin{array}{l}\text { Affect, cognitive competence, value, } \\
\text { difficulty, interest, effort }\end{array}$ \\
\hline & $\begin{array}{l}\text { MSQ: Motivation toward Statistics } \\
\text { Ouestionnaire (Budé et al.. 2007) }\end{array}$ & $\begin{array}{l}\text { Stable explanation, control, outcome } \\
\text { expectancy, affect, effort, persistence }\end{array}$ \\
\hline
\end{tabular}

one-dimensional, which is an untenable assumption according to most attitude theories (Albarracin, Johnson, \& Zanna, 2005). It is difficult to use assessment results to effectively improve instruction and student course outcomes without theoretical guidance. The SAS also has been criticized as some of the items assess students' knowledge about statistics concepts or problems, not their attitudes (Curda, 1997; Gal \& Ginsburg, 1994; Rhoads \& Hubele, 2000; Sorge, 2001; Wise, 1985). Accordingly, it should not be used at the beginning of the introductory course (Rhoads \& Hubele, 2000; Waters, Martelli, Zakrajsek, \& Popovich, 1988). Like most of these surveys, the SAS was developed without input from its intended users, statistics students and instructors (except for the surveys' creators).

In an attempt to solve some of these problems, Wise (1985) developed his ATS. According to Wise, the ATS does not require knowledge about statistics and so can be used on the first day of class. 
He claimed that the ATS measures two separate components of students' attitudes: "Field" "attitudes of students toward the use of statistics in their field of study" and "Course" - "students" attitudes toward the course in which they were enrolled" (p. 402). Although the ATS has been widely used, it also exhibits problems. For example, it is not clear why Wise chose to develop these two specific components and only these two. These two components do not cover the construct of attitudes toward statistics (Curda, 1997; Gal \& Ginsburg, 1994; Rhoads \& Hubele, 2000; Sorge, 2001). Even though the definitions of his two components are quite broad, some items do not appear to fit into their designated component or even into the other component. The ATS also was not based on theory and was developed without input from users.

\subsection{THE SURVEY OF ATTITUDES TOWARD STATISTICS}

Beginning in the early 1990s, Schau developed the Survey of Attitudes Toward Statistics-28 (SATS-28) followed by the Survey of Attitudes Toward Statistics-36 (SATS-36) to ameliorate the issues associated with earlier attitude surveys. The SATS-28 contained 28 items assessing four attitude components: Affect, Value, Cognitive Competence, and Difficulty. A decade later, Schau updated the SATS- 28 by adding 8 more items measuring two additional attitude components, Effort and Interest, and named the revised version the Survey of Attitudes Toward Statistics-36 (SATS-36). The eight-step qualitative and quantitative development process used across the development of the two versions of the SATS included

1. initial examination of surveys purporting to assess students' attitudes toward statistics,

2. introductory statistics students' written descriptions of their attitudes,

3. words and phrases describing statistics students' attitudes generated and sorted into a consensus component structure by a focus group of introductory statistics' students and instructors,

4. pilot testing and subsequent revision of items written from these words and phrases,

5. validation of the four-component internal structure generated in Step 3 using Confirmatory Factor Analysis techniques,

6. validation of component scores based on their relationships and lack of relationships with scores from other measures,

7. addition of two more attitude components, and

8. validation of the six-component internal structure using Confirmatory Factor Analysis techniques.

The SATS-36 contains 36 items that assess six attitude components that are congruent with theories and research findings. These components include: Affect, Cognitive Competence, Value, Difficulty, Interest, and Effort. Students respond to each of the SATS items using a 7-point Likert response scale (1 = "Strongly Disagree", 4 = "Neither Disagree nor Agree" or neutral, 7 = "Strongly Agree"). Because higher item responses reflect more positive attitudes, responses to items that are negatively worded are reversed before combining students' responses into component scores. Thus, higher scores for every component (except for Difficulty) also reflect more positive attitudes. Students with higher Difficulty scores believe that statistics is easier whereas those with lower scores believe that it is harder. Although the name of the Difficulty component is not ideal, the focus group that contributed to the development of the SATS-28 named this component, and it has been known as such throughout the history of the use of the SATS. Table 2 contains each of the six SATS-36 components, its definition, and example item(s) from the pretest version.

The SATS-36 also contains additional items that assess Student Characteristics, such as gender and age, and students' Previous Achievement-Related Experiences, such as "number of high school mathematics and/or statistics courses completed." The items that do not use a Likert response scale are either in a "select" response format (e.g., gender) or a "fill-in" format (e.g., number of courses). Students usually spend about 10-15 minutes responding to the items on the SATS administered in either a paper-and-pencil or a Web format. The SATS pre-tests can be viewed at www.evaluationandstatistics.com. 
Table 2. SATS-36 attitude components, definitions, and example item(s) from www.evaluationandstatistics.com

\begin{tabular}{|c|c|c|}
\hline Component & Definition & Example Item(s) \\
\hline $\begin{array}{l}\text { Affect } \\
\text { (6 items) }\end{array}$ & $\begin{array}{l}\text { "students' feelings concerning } \\
\text { statistics" }\end{array}$ & "I am scared by statistics." \\
\hline $\begin{array}{l}\text { Cognitive } \\
\text { Competence } \\
\text { (6 items) }\end{array}$ & $\begin{array}{l}\text { "students' attitudes about their } \\
\text { intellectual knowledge and skills when } \\
\text { applied to statistics" }\end{array}$ & "I can learn statistics." \\
\hline $\begin{array}{l}\text { Value } \\
\text { (9 items) }\end{array}$ & $\begin{array}{l}\text { "students' attitudes about the } \\
\text { usefulness, relevance, and worth of } \\
\text { statistics in personal and professional } \\
\text { life" }\end{array}$ & $\begin{array}{l}\text { "I use statistics in my everyday } \\
\text { life." } \\
\text { "Statistics is not useful to the typical } \\
\text { professional." }\end{array}$ \\
\hline $\begin{array}{l}\text { Difficulty } \\
\text { ( } 7 \text { items) }\end{array}$ & $\begin{array}{l}\text { "students' attitudes about the difficulty } \\
\text { of statistics as a subject" }\end{array}$ & $\begin{array}{l}\text { "Most people have to learn a new } \\
\text { way of thinking to do statistics." }\end{array}$ \\
\hline $\begin{array}{l}\text { Interest } \\
\text { (4 items) }\end{array}$ & $\begin{array}{l}\text { "students' level of individual interest in } \\
\text { statistics" }\end{array}$ & "I am interested in using statistics." \\
\hline $\begin{array}{l}\text { Effort } \\
\text { (4 items) }\end{array}$ & $\begin{array}{l}\text { "amount of work the student expends to } \\
\text { learn statistics" }\end{array}$ & $\begin{array}{l}\text { "I plan to work hard in my statistics } \\
\text { course." }\end{array}$ \\
\hline
\end{tabular}

Several studies have shown that scores from the SATS have good to excellent psychometric properties. These properties include moderate to high values for internal consistencies for each of the attitude components evaluated using Cronbach's coefficient alpha (i.e., how well the items as a group fit together into their component) and concurrent validity (i.e., if the component scores show expected patterns of relationships with scores from other measures). Also, the six-component internal structure fits student responses to the 36 items well. This psychometric evidence comes from studies that included female and male students with varying educational levels (undergraduate or graduate), majors, ethnicities (e.g., White, Hispanic), and nationalities (e.g., German, Dutch, Italian, South African); different times of administration (usually beginning and end of the course); and a variety of course, instructor, instructional, and institutional characteristics. See, for example, Bechrakisa, Gialamasb, and Barkatsas (2011), Carnell (2008), Chiesi and Primi (2009), Dauphinee, Schau, and Stevens (1997), Emmioğlu (2011), Hilton, Schau, and Olsen (2004), Schau et al. (1995), Tempelaar and Nijhuis (2007), Tempelaar, Schim van der Loeff, and Gijselaers (2007), and Verhoeven (2009). Additional references are found at http://www.evaluationandstatistics.com.

\section{A MODEL OF STUDENTS’ ATTITUDES TOWARD STATISTICS}

Why do some students perform better or value statistics more than other students? Why do they make certain academic and life choices regarding statistics and not others? We developed a broad conceptual model called a Model of Students' Attitudes Toward Statistics (or SATS-M) that will help us start to systematically explore the possible answers to these kinds of questions. The SATS-M contains three main constructs that influence Statistics Course Outcomes.

Student Characteristics is the first general construct. These characteristics can include, for example, gender and age, as well as any other demographic characteristic of interest. The second construct is Previous Achievement-Related Experiences; these experiences can include, for example, grade point average and past experiences with statistics and mathematics.

The third general construct is Statistics Attitudes; this construct includes any attitudinal variable considered to be important. In our case, it includes the six attitude components from the SATS- 36 . Before devoting the time and energy (Effort) to learn and do statistics, our model indicates that students evaluate their skills (Cognitive Competence) and the Difficulty of statistics and statistics tasks. They choose to expend Effort on statistics tasks and courses that they like (Affect) and are interested in doing (Interest) while they avoid others. They also consider how useful statistics is and will be in their lives (Value). 


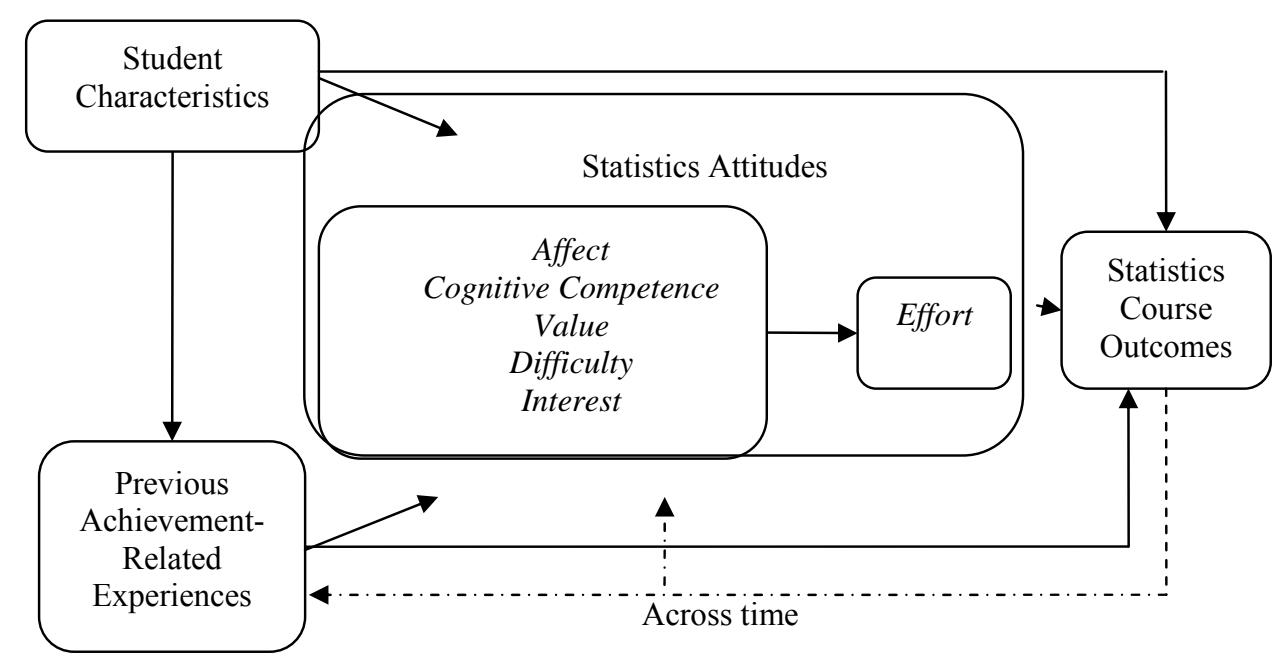

Figure 1. Students’ Attitudes Toward Statistics - Model (SATS-M)

The constructs in our model emphasize the multi-dimensional and longitudinal nature of students' attitudes and Course Outcomes. Our model suggests that Student Characteristics influence Previous Achievement-Related Experiences and both impact Statistics Attitudes; all three then influence Statistics Course Outcomes. For example, male and female students may have taken different mathematics courses and achieved at different levels in those courses. Those experiences may impact their Statistics Attitudes and together result in different Statistics Outcomes by student gender. Longitudinally, Statistics Course Outcomes then impact Previous Achievement-Related Experiences and Statistics Attitudes. This kind of framework can help instructors and researchers consider factors that directly and indirectly influence students' attitudes toward statistics and their course outcomes, as well as how these relationships work.

\section{THEORETICAL SUPPORT FOR THE IMPORTANCE OF STATISTICS ATTITUDES AND THE SATS-M}

We primarily used Eccles' Expectancy-Value Theory as a general framework to develop the SATS-M. In addition, we reviewed other theories to verify the importance of the constructs found in our model. See below for a brief description of Eccles' EVT, as well as three additional theories. For more information on these theories and others, see Wentzel and Wigfield (2009).

\subsection{ECCLES' EVT}

Eccles and colleagues' revision of earlier Expectancy-Value Theories is one of the most influential and comprehensive theories designed to explain the nature of individuals' academic behaviors (Wigfield \& Eccles, 2002). Eccles and colleagues, as well as many other researchers, have successfully applied their EVT to K-12 students' academic choices and achievement in many domains, including mathematics.

Eccles' EVT posits that students' beliefs about how well they will do on a task and how much they value that task are related and that they predict students' achievement-related outcomes. In other words, Eccles' EVT indicates that students are more likely to choose to engage and achieve in tasks that they value in broad terms and in which they expect to do well. In statistics education, these tasks include, for example, enrolling in and completing statistics courses, working hard to learn and to achieve, and using statistics in life.

Eccles and colleagues conceptualize value (called Subjective Task Value) as a "super-construct" that cannot be measured but that includes several measurable components, including students' interest in (Interest) and enjoyment from (Affect) engaging in a task, the importance a student attaches to the task and the usefulness of the task to students' futures (Value), and how much Effort it will take to 
accomplish the task. In addition, Eccles' EVT includes the constructs of task difficulty (Difficulty) and self-concept of abilities (Cognitive Competence).

Their theory also includes the impacts of Student Characteristics and Previous AchievementRelated Experiences on attitudes and other outcomes. A large body of research in disciplines other than statistics education has used Eccles' EVT as a theoretical framework. The results from this research support the predictions made by their theory (e.g., Bøe, Henriksen, Lyons, \& Schreiner, 2011; Bruinsma, 2004; Durik, Vida, \& Eccles, 2006; Luttrell et al., 2010; Simpkins, Davis-Kean, \& Eccles, 2006).

\subsection{OTHER THEORIES}

We briefly mention three other theories that support our work. These theories include Selfdetermination Theory, Self-efficacy Theory, and Achievement Goal Theory.

Self-determination Theory Like Eccles' EVT, this theory proposes that students' learning is influenced by how they feel about statistics (Affect), their Interest in statistics, how much they Value statistics, and their beliefs in their cognitive abilities to cope with statistics (Cognitive Competence). Considerable research in this area has shown that students who feel competent and are engaged in interesting, enjoyable, and valued tasks tend to learn more than students whose attitudes in these four areas are less positive (e.g., Ryan \& Deci, 2009).

Self-efficacy Theory This theory suggests that students who have positive judgments of their capabilities (Cognitive Competence) perform better than those who do not (e.g., Bandura, 1986, 1997; Gist \& Mitchell, 1992). Usher and Pajares (2008) claimed that students' interpretation of their previous achievement is the most influential source of their self-efficacy. According to this theory, students typically base their self-efficacy on their evaluation and interpretation of their prior experience in current or similar past courses; their resulting self-efficacy then will inform their decisions to engage in behaviors that result in Statistics Course Outcomes (both good and bad).

Achievement Goal Theory According to this theory, students value or devalue statistics for many possible reasons. The ways in which students Value a particular outcome or task informs their choices and influences their behavior, as well as the Effort that they are willing to expend toward achieving a goal.

\section{SATS EMPIRICAL FINDINGS RELATED TO THE SATS-M}

Because the developers of the surveys designed to assess students' attitudes toward statistics disagreed about such fundamentals as the number of attitude components (ranging from 1 to 6), as well as the constructs they assess, it is difficult (if not impossible) to summarize results from research using different attitude surveys. Given the extensive research supporting the psychometric qualities of scores from the SATS-28 and the SATS-36 and our choice to include the six SATS-36 components in our model, we summarized findings from research that has used one or the other version of the SATS.

We identified 59 studies that used the SATS-28 or the SATS-36: 15 conference proceedings, 12 dissertations, and 32 journal articles. About $90 \%$ percent of these studies were done in the last 12 years; there has been an increase in the number of studies that have used the SATS-28 or SATS-36 since 2003, soon after the development of the SATS-28. Of these studies, three (5\%) used a pretestposttest design, 11 (18\%) exploreded the psychometric propoerties of the SATS-28/36, $10(16 \%)$ tested structural equation models, $14(23 \%)$ evaluated an intervention, and 21 (35\%) were correlational studies.

Results from the research using the SATS generally support the existence of the relationships contained in our Students' Attitudes Toward Statistics - Model. However, it is difficult to discuss definitive patterns in the research findings from these studies for at least five reasons. First, 38 researchers used the SATS-28, three used only selected components from the SATS-28, and 18 used the complete SATS-36. This variation means that some of the SATS components, especially Interest and Effort that are found only in the SATS-36, were not included in almost $70 \%$ of the studies. 
Second, the samples varied greatly in terms of demographic and achievement-related characteristics, including, for example, the proportion of females to males, age, educational level (undergraduate students, graduate students, mixed), students' nationality (e.g., US, Netherlands, Italy, South Africa, Israel, Greece), and major (e.g., business, psychology, pre-service teaching training, mixed). Third, these characteristics themselves were interrelated; for example, the sample from Israel was almost entirely female and all were enrolled in the pre-service teacher training program. Fourth, Previous Achievement and course achievement (the most commonly studied Course Outcome) were measured in a variety of ways (e.g., course grades, exam scores, self-reported math ability). Fifth, sample sizes (and so the ease of finding statistical significance) varied widely.

Next, we examine and discuss the empirical results in two sections, organized by the constructs found in our model. We first summarize findings from research that examined the relationships among prior factors and Statistics Attitudes. We then summarize research results relating previous factors and Statistics Course Outcomes.

\subsection{RELATIONSHIPS AMONG PRIOR SATS-M FACTORS AND STATISTICS ATTITUDES}

Two SATS-M factors impact Statistics Attitudes. These factors include Student Characteristics and Previous Achievement-Related Experiences.

Student Characteristics Student Characteristics is the first factor in our model that impacts Statistics Attitudes. The most commonly studied characteristics include gender, ethnicity/nationality, and age.

We identified 17 studies that investigated possible gender differences in attitude components; these studies did not reveal consistent findings. Nine, all from countries other than the United States, reported some statistically significant gender differences on some attitude components (Bechrakisa et al., 2011; Coetzee \& van der Merwe, 2010; Mahmud \& Zainol, 2008; Tempelaar, Schim van der Loeff, Gijselaers, \& Nijhuis, 2011; Tempelaar, Gijselaers, \& Schim van der Loeff, 2006; Tempelaar \& Nijhuis, 2007; Tempelaar \& Schim van der Loeff, 2011; Verhoeven, 2009, 2011). Males, on average, reported more positive attitudes than females on Affect, Cognitive Competence, and Difficulty. Researchers only found one component, Effort, with females reporting more positive mean attitudes (i.e., more Effort) than males. Another eight studies, all conducted in the United States, reported that female and male students' attitudes, on average, did not differ on any component (Carnell, 2008; Cashin \& Elmore, 2005; Faghihi \& Rakow, 1995; Pierce, 2006; Schau, Dauphinee, \& Del Vecchio, 1992; Scott, 2001; Watson, Lang, \& Kromrey, 2002; Watson et al., 2003). Results from these studies suggest that gender differences may vary based on the component assessed, students' nationalities, when their attitudes are measured, and what subjects they are studying at the time of assessment.

Seven studies investigated mean differences in component scores associated with ethnicity/nationality. Five of them reported statistically significant mean differences in Statistics Attitudes across different ethnic/nationality groups (Ruggeri et al., 2008; Tempelaar et al., 2006; Tempelaar \& Nijhuis, 2007; Watson et al., 2002, Watson et al., 2003), and two studies did not (Schau et al., 1992; Pierce, 2006). These studies included students who identified themselves as: Spanish, British, American, Austrian, German or other (Ruggeri et al., 2008); Dutch or International (Tempelaar et al., 2006); Dutch or German (Tempelaar \& Nijhuis, 2007); White American, Non-white American, or Foreign (Watson et al., 2002, Watson et al., 2003); White American, Native American, African-American, or Hispanic American (Schau et al.); and White American, Asian American, African American, or Other American (Pierce, 2006). Because the ethnic/nationality groups studied varied widely across studies, it is not possible to summarize or generalize these findings.

Three studies have examined the relationships among student age and component scores (Coetzee $\&$ van der Merwe, 2010; Scott, 2001; Verhoeven, 2009). However, the components and the direction of the relationships with age differed. In addition, each of these studies was conducted in a different country and so the nationalities of the students involved differed. These findings cannot be summarized or generalized. 
Previous Achievement-Related Experiences We identified 10 studies that investigated the relationships among selected Previous Achievement-Related Experiences, the second factor in the SATS-M, and Attitudes; all 10 found at least some statistically significant relationships. The most commonly studied Experiences included those related to statistics or to mathematics. In all cases, scores from these measures were statistically significantly and positively related to attitude components (Carmona, Martinez, \& Sanchez, 2005; Cashin \& Elmore, 2005; Chiesi \& Primi, 2010; Coetzee \& van der Merwe, 2010; Dempster \& McCorry, 2009; Mills, 2004; Scott, 2001; Sorge, 2001; Tempelaar \& Schim van der Loeff, 2011; Verhoeven, 2009). Students with more experience and higher past achievement reported more positive attitudes for some components, especially Affect, Cognitive Competence, and Difficulty.

\subsection{RELATIONSHIPS AMONG PRIOR SATS-M FACTORS AND COURSE OUTCOMES}

The SATS-M indicates that three factors impact Statistics Course Outcomes. These factors include Student Characteristics, Attitudes, and Previous Achievement-Related Experiences.

Student Characteristics We identified three studies that included the use of the SATS-28 or the SATS-36 but also investigated the relationships among Student Characteristics and Statistics Outcomes (Schutz, Drogosz, White \& Distefano, 1998; Tempelaar et al., 2006; Verhoeven, 2009). Because of the dearth of studies and the differences in measures used to assess Outcomes, these findings cannot be summarized or generalized.

Previous Achievement-Related Experiences We identified six studies that examined the relationships among Previous Experiences and achievement. All six studies reported statistically significant and positive relationships (Carlson \& Winquist, 2011; Chiesi \& Primi, 2010; Schutz et al., 1998; Sorge, 2001; Verhoeven, 2011; Wisenbaker, Scott \& Nasser, 1999). As expected, students with more experience and prior success achieved at higher levels in their statistics courses.

Statistics Attitudes We found 17 studies that examined the relationships among attitudes and achievement. Of these studies, 15 reported statistically significant and positive relationships among selected attitude components and achievement (Carlson \& Winquist, 2011; Cashin \& Elmore, 2005; Chiesi \& Primi, 2009, 2010; Dempster \& McCorry, 2009; Emmioğlu, 2011; Estrada, Batanero, Fortuny \& Diaz, 2005; Nasser, 2004; Schutz et al., 1998; Sorge, 2001; Schau, 2003b; Verhoeven, 2009, 2011; Tempelaar et al., 2006; Tempelaar et al., 2007). That is, more positive attitudes were associated with higher achievement in students' statistics courses. The components that exhibited these relationships most often included Affect, Cognitive Competence, and Value; Difficulty rarely was related to achievement. These four components are found in both versions of the SATS. Two studies did not report statistically significant relationships among any of the four SATS-28 components and achievement (Scott, 2001; Wisenbaker et al., 1999).

\section{IMPLICATIONS AND CONCLUSIONS}

What outcomes are important from an introductory statistics course? We want students to complete their courses able to engage in statistical thinking. We want them to use statistical thinking accurately in their other courses, in their professions, and in their lives. We hope that some of these students choose to take other statistics courses and even minor or major in statistics. How do we accomplish these goals?

A plethora of theories suggest that students' attitudes can lead them to make these choices and engage in these behaviors. The results from many research studies in disciplines other than statistics education show that the constructs found in Eccles' EVT predict achievement-related choices and performance both in and out of classes in a variety of domains (e.g., Bruinsma, 2004; Cocks \& Watt, 2004; Eccles, 1983; Greene, DeBacker, Ravindran, \& Krows, 1999; Simpkins et al., 2006; Watt, 2005; Wigfield \& Tonks, 2002). Even though we believe that students' attitudes toward statistics are important, we know relatively little about them and their impacts on statistics course outcomes. Fifteen years ago, Gal, Ginsburg, and Schau (1997) noted that the lack of theory-based work has 
contributed to the dearth of research in this area (and to the difficulty in applying results from this research to instruction). We hope that we have started to bridge this gap with the creation of our SATS-M.

Our model indicates that all of its constructs should be interrelated and that they impact important Course Outcomes (including Attitudes themselves). Results from much of the research using the SATS-28 and the SATS-36 support the existence of the relationships among the constructs contained in our model. These research findings suggest that the relationships among Student Characteristics and Statistics Attitudes are complex. Gender differences were not found in the studies conducted in the United States. However, in other countries, males in general liked statistics better, thought they had better knowledge and skills, and did not think that statistics was as hard, whereas females indicated that they worked harder in statistics. This pattern suggests that we need to consider multiple Student Characteristics concurrently and engage in planned consistent research across countries.

Some researchers have studied the relationships among Previous Achievement-Related Experiences (mostly commonly, statistics and mathematics experiences) and both Attitudes and Outcomes (assessed as achievement). Most of these researchers have reported positive relationships. That is, students with more previous experience or higher prior achievement in statistics and/or mathematics reported more positive attitudes on some components, especially Affect, Cognitive Competence, and Difficulty; they also achieved at a higher level. This pattern was consistent even though both Previous Achievement-Related Experiences and achievement have been assessed in a variety of ways.

Unfortunately, achievement is the Statistics Course Outcome that has been most frequently assessed. Most researchers who have examined the relationships among attitude components and achievement have reported positive relationships. Students with more positive Affect, Cognitive Competence, and Value achieve better in their statistics courses. As expected, these relationships were stronger when attitudes and achievement were measured closer together in time.

These studies represent a beginning in exploring the relationships among Student Characteristics, Previous Achievement-Related Experiences, Statistics Attitudes, and Statistics Course Outcomes. Their results demonstrate that some relationships consistently exist. A great deal more research is needed, including using meta-analysis to explore the sizes of the effects found in this research. To date, however, little attempt has been made to systematically examine these relationships. To be most useful, this research should be large scale, include common measures of the constructs found in the SATS-M, use one or more common research procedures, and sample using stratified techniques both within and outside of the United States.

In addition, as Eccles and others have worked on the EVT, it has evolved, as models and theories should, both in terms of where measurable components fit within super-constructs as well as with proposed relationships among super-constructs. In addition, research based on the EVT often omits some measurable components and varies the directions of the relationships among components. In spite of these differences across versions of Eccles' EVT and the research using it, EVT is useful to us in statistics education. To allow flexibility, we did not indicate the directions linking the first five attitude components in the SATS-M. A variety of possible directions exist for these links that are congruent with one or more versions of EVT and/or research based on it, yielding an interesting area for future research.

The American Statistical Association has endorsed the Guidelines for Assessment and Instruction in Statistics Education (GAISE; Franklin \& Garfield, 2006). Efforts to promote and improve statistics education raise many important instructional and research questions. For example, we need to know which GAISE-consistent instructional contexts, approaches, and activities are most effective in helping students develop more positive attitudes and hence in improving their engagement in learning.

Most of the instructional innovations in statistics education are based on teachers' intuitions about what will work. Statistics educators believe that instructors can influence students' achievement, attitudes toward statistics, and other outcomes through adapting instruction accordingly, for example by developing and maintaining students' interests and by illustrating the reasons for learning statistics (e.g., Bartsch, 2006; Evans, 2007; Mills, 2004; Rhoads \& Hubele, 2000). However, these instructional approaches and the activities that result from them usually are not based explicitly on educational theories or models. In addition, often the effects of these implementations are not evaluated, so little evidence exists to support their efficacy. Instructors' experiences are critical but we need solid theory- 
based evidence about what does and does not work and for whom. We believe that we can improve statistics education by using models of attitudes, like the SATS-M, to guide our development and implementation of instructional interventions. We can obtain evidence of the effectiveness of these interventions and of our courses by using good measures such as the SATS-36.

People forget what they do not use. But attitudes "stick." Positive attitudes keep us using what we have learned. They also encourage us to seek opportunities to learn more. It is for these reasons that we believe that students' attitudes are the most important and influential outcome from introductory statistics courses.

\section{ACKNOWLEDGEMENTS}

The research reported in this paper was supported partially by the Consortium for the Advancement of Undergraduate Statistics Education (CAUSE), through NSF Award \#0618790. We are grateful to the organizers of the USCOTS 2009 (United States Conference On Teaching Statistics) for starting our Attitudes Research Cluster.

\section{REFERENCES}

Albarracin, D., Johnson, B. T., \& Zanna, M. (Eds.). (2005). The handbook of attitudes. Mahwah, NJ: Lawrence Erlbaum

Auzmendi, E. (1991, April). Factors related to attitudes toward statistics: A study with a Spanish sample. Paper presented at the annual meeting of the American Educational Research Association, Chicago.

Bandura, A. (1986). Social foundations of thought and action: A social cognitive theory. Englewood Cliffs, NJ: Prentice Hall.

Bandura, A. (1997). Self-efficacy: The exercise of control. New York: Freeman.

Bartsch, R. A. (2006). Improving attitudes toward statistics in the first class. Teaching of Psychology, 33(3), 197-198.

Bayot, A., Mondejar, J., Mondejar, J. A., Monsalve, F., \& Vargas, M. (Eds.). (2005). The difficulties of learning concepts in the social science. Krakow, Poland: Wydawnictwo Naukowe Akademii Pedagogicznej.

Bechrakisa, T., Gialamasb, V., \& Barkatsas, A. N. (2011). Survey of Attitudes Toward Statistics (SATS): An investigation of its construct validity and its factor structure invariance by gender. International Journal of Theoretical Educational Practice, 1(1), 1-15.

Bøe, M. V., Henriksen, E. K., Lyons, T., \& Schreiner, C. (2011). Participation in Science and Technology: Young people's achievement-related choices in late modern societies. Studies in Science Education, 47(1), 1-36.

[Online: http://www.naturfagsenteret.no/binfil/download.php?did=7061]

Bruinsma, M. (2004). Motivation, cognitive processing and achievement in higher education, Learning and Instruction, 14(6), 549-568.

Budé, L., Van De Wiel, M. W. J., Imbos, T., Candel, M. J. J. M., Broers, N. J., \& Berger, M. P. F. (2007). Students' achievements in a statistics course in relation to motivational aspects and study behavior. Statistics Education Research Journal,6(1), 5-21.

[Online: http://www.stat.auckland.ac.nz/ iase/serj/SERJ6\%281\%29 Bude.pdf]

Carlson, K. A., \& Winquist, J. R. (2011). Evaluating an active learning approach to teaching introductory statistics: A classroom workbook approach. Journal of Statistics Education, 19(1). [Online: http://www.amstat.org/publications/jse/v19n1/carlson.pdf]

Carmona, J., Martinez, R. J., \& Sanchez, M. (2005). Mathematical background and attitudes toward statistics in a sample of Spanish college students. Psychological Reports, 97(1), 53-62.

Carnell, L. J. (2008). The effect of a student-designed data collection project on attitudes toward statistics. Journal of Statistics Education, 16(1).

[Online: http://www.amstat.org/publications/jse/v16n1/carnell.html]

Cashin, S. E., \& Elmore, P. B. (2005). The Survey of Attitudes Toward Statistics scale: A construct validity study. Educational and Psychological Measurement, 65(3), 509-524. 
Chiesi, F., \& Primi, C. (2009). Assessing statistics attitudes among college students: Psychometric properties of the Italian version of the Survey of Attitudes Toward Statistics (SATS). Learning and Individual Differences, 19(2), 309-313.

Chiesi, F., \& Primi, C. (2010). Cognitive and non-cognitive factors related to students' statistics achievement. Statistics Education Research Journal, 9(1), 6-26.

[Online: http://www.stat.auckland.ac.nz/ iase/serj/SERJ9\%281\%29 Chiesi Primi.pdf]

Cocks, R. J., \& Watt, H. M. G. (2004). Relationships among perceived competence, intrinsic value and mastery goal orientation in English and maths. The Australian Educational Researcher, 31(2), 81-111.

Cruise, R. J., Cash, R. W., \& Bolton, D. L. (1985, August). The development and validation of an instrument to measure statistical anxiety. Paper presented at the meeting of the American Educational Research Association, Chicago.

Coetzee, S., \& van der Merwe, P. (2010). Industrial psychology students' attitudes towards statistics. SA Journal of Industrial Psychology, 36(1), 1-8.

Curda, S. K. (1997). Learners' motivational characteristics in statistics: A causal model (Unpublished doctoral dissertation). University of Oklahama, Norman, OK.

Dauphinee, T. L., Schau, C., \& Stevens, J. J. (1997). Survey of Attitudes Toward Statistics: Factor structure and factorial invariance for women and men. Structural Equation Modeling, 4(2), 129 141.

Dempster, M., \& McCorry, N. K. (2009). The role of previous experience and attitudes toward statistics in statistics assessment outcomes among undergraduate psychology students. Journal of Statistics Education, 17(2).

[Online: http://www.amstat.org/publications/jse/v17n2/dempster.html]

Durik, A. M., Vida, M., \& Eccles, J. S. (2006). Task values and ability beliefs as predictors of high school literacy choices: A developmental analysis. Journal of Educational Psychology, 98(2), 382-393.

Eccles, J. S. (1983). Expectancies, values, and academic behaviors. In J. T. Spence (Ed.), Achievement and achievement motives: Psychological and sociological approaches ( $\mathrm{pp}$. 75-145). San Francisco: W. H. Freeman and Company.

Emmioğlu, E. (2011). A structural equation model examining the relationships among mathematics achievement, attitudes toward statistics, and statistics outcomes (Unpublished doctoral dissertation). Middle East Technical University, Ankara, Turkey.

Estrada A., Batanero, C., Fortuny, J. M., \& Diaz, C. (2005, February). A structural study of future teachers' attitudes towards statistics. Paper presented at the Fourth European Conference in Mathematics Education, Sant Felliu de Guissols.

Evans, B. (2007). Student attitudes, conceptions, and achievement in introductory undergraduate college statistics. The Mathematics Educator, 17(2), 24-30.

[Online: http://math.coe.uga.edu/tme/issues/v17n2/v17n2_Evans.pdf]

Faghihi, F., \& Rakow, E. A. (1995, November). The relationship of instructional methods with student responses to the Survey of Attitudes Toward Statistics. Paper presented at the annual meeting of the Mid-South Educational Research Association, Biloxi.

Finney, S. J., \& Schraw, G. (2003). Self-efficacy beliefs in college statistics courses. Contemporary Educational Psychology, 28(2), 161-186.

Franklin, C. A., \& Garfield J. B. (2006).The GAISE project: Developing statistics education guidelines for grades pre-K-12 and college courses. In G. F. Burill \& P. C. Elliott (Eds.), Thinking and reasoning with data and chance: 68th NCTM yearbook (pp. 345-375). Reston, VA: National Council of Teachers of Mathematics.

Gal, I., \& Ginsburg, L. (1994). The role of beliefs and attitudes in learning statistics: Towards an assessment framework. Journal of Statistics Education, 2(2).

[Online: http://www.amstat.org/publications/jse/v2n2/gal.html]

Gal, I., Ginsburg, L., \& Schau, C. (1997). Monitoring attitudes and beliefs in statistics education. In I. Gal \& J. B. Garfield (Eds.), The assessment challenge in statistics education (pp. 37-51). Amsterdam: IOS Press.

[Online: http://www.stat.auckland.ac.nz/ iase/publications/assessbk/chapter04.pdf] 
Garfield, J., Hogg, B., Schau, C., \& Whittinghill, D. (2002). First courses in statistical science: The status of educational reform efforts. Journal of Statistics Education, 10(2).

[Online: http://www.amstat.org/publications/jse/v10n2/garfield.html]

Gist, M. E., \& Mitchell, T. R. (1992). Self-efficacy: A theoretical analysis of its determinants and malleability. Academy of Management Review, 17(2), 183-211.

Greene, B. A., DeBacker, T. K., Ravindran, B., and Krows, A. J. (1999). Goals, values, and beliefs as predictors of achievement and effort in high school mathematics classes. Sex Roles, 40(5), 421458.

Harlow, L. L., Burkholder, G. J., \& Morrow, J. A. (2002). Evaluating attitudes, skill, and performance in a learning-enhanced quantitative methods course: A structural modeling approach. Structural Equation Modeling, 9(3), 413-430.

Hilton, S. C., Schau, C., \& Olsen, J. A. (2004). Survey of Attitudes Toward Statistics: Factor structure invariance by gender and by administration time. Structural Equation Modeling, 11(1), 92-109.

Lane, A., Hall, R., \& Lane, J. (2002). Development of a measure of self-efficacy specific to statistics courses in sport. Journal of Hospitality, Leisure, Sport and Tourism Education, 1(2), 47-56.

[Online: http://www.heacademy.ac.uk/assets/hlst/documents/johlste/0017 lane vollno2.pdf]

Luttrell, V. R., Callen, B. W., Allen, C. S., Wood, M. D., Deeds, D. G., \& Richard, D. C. S. (2010). The mathematics value inventory for general education students: Development and initial validation. Educational and Psychological Measurement, 70(2), 142-160.

Mahmud, Z., \& Zainol, M. S. (2008). Examining postgraduate students' perceived competency in statistical data analysis and their attitudes toward statistics. International Journal of Education and Information Technologies, 1(2), 79-86.

Mills, J. D. (2004). Students' attitudes toward statistics: Implications for the future. College Student Journal, 38(3), 349-361.

Nasser, F. M. (2004). Structural model of the effects of cognitive and affective factors on the achievement of Arabic-speaking pre-service teachers in introductory statistics. Journal of Statistics Education, 12(1).

[Online: http://www.amstat.org/publications/jse/v12n1/nasser.html]

National Council of Teachers of Mathematics. (1989). Curriculum and evaluation standards for school mathematics. Reston, VA: NCTM.

National Council of Teachers of Mathematics. (1991). Professional standards for teaching mathematics. Reston, VA: NCTM.

Pierce, R. L. (2006). SATS at Ball State University: Approaches and attitudes. In A. Rossman \& B. Chance (Eds.), Working cooperatively in statistics education: Proceedings of the Seventh International Conference on Teaching Statistics, Salvador, Brazil. [CDROM]. Voorburg, The Netherlands: International Statistical Institute.

[Online: http://www.stat.auckland.ac.nz/ iase/publications/17/C116.pdf]

Rhoads, T. R., \& Hubele, N. F. (2000). Student attitudes toward statistics before and after a computerintegrated introductory statistics course. IEEE Transactions on Education, 43(2), 182-187.

Roberts, D. M., \& Bilderback, E. W. (1980). Reliability and validity of a statistics attitude survey. Educational and Psychological Measurement, 40(1), 235-238.

Roberts, D. M., \& Saxe, J. E. (1982). Validity of a statistics attitude survey: A follow up study. Educational and Psychological Measurement, 42(3), 907-912.

Ruggeri, K., Díaz, C., Kelley, K., Papousek, I., Dempster, M., \& Hana, D. (2008). International issues in education. Psychology Teaching Review, 14(2), 65-74.

Ryan, R. M., \& Deci, E. L. (2009). Promoting self-determined school engagement: Motivation, learning, and well-being. In K. R. Wentzel \& A. Wigfield (Eds.), Handbook of motivation at school (pp. 171-196). New York: Routledge.

Schau, C. (1992). Survey of Attitudes Toward Statistics (SATS-28).

[Online: http://evaluationandstatistics.com/]

Schau, C. (2003a). Survey of Attitudes Toward Statistics (SATS-36).

[Online: http://evaluationandstatistics.com/]

Schau, C. (2003b, August). Students' attitudes: The "other" important outcome in statistics education. Paper presented at the Joint Statistical Meetings, San Francisco, CA.

[Online: http://evaluationandstatistics.com/JSM2003.pdf] 
Schau, C., Dauphinee, T., \& Del Vecchio, A. D. (1992, April). The development of the Survey of Attitudes Toward Statistics. Paper presented at the annual meeting of the American Educational Research Association, San Francisco.

Schau, C., Stevens, J., Dauphinee, T. L., \& Del Vecchio, A. (1995). The development and validation of the Survey of Attitudes Toward Statistics. Educational and Psychological Measurement, 55(5), 868-875.

Schutz, P. A., Drogosz , L. M., White, V. E., \& Distefano, C. (1998). Prior knowledge, attitude, and strategy use in an introduction to statistics course. Learning and Individual Differences, 10(4), 291-308.

Scott, J. S. (2001). Modeling aspects of students' attitudes and performance in an undergraduate introductory statististics course (Unpublished doctoral dissertation). The University of Georgia, Athens, Georgia.

Simpkins, S. D., Davis-Kean, P. E., \& Eccles, J. S. (2006). Math and science motivation: A longitudinal examination of the links between choices and beliefs. Developmental Psychology, $42(1), 70-83$.

Sorge, C. (2001). Impact of engineering students' attitudes on achievement in statistics: A structural equation model analysis (Unpublished doctoral dissertation). The University of New Mexico, Albuquerque, New Mexico.

Tempelaar, D. T., Gijselaers, W. J., \& Schim van der Loeff, S. (2006). Puzzles in statistical reasoning. Journal of Statistics Education, 14(1).

[Online: http://www.amstat.org/publications/jse/v14n1/tempelaar.html]

Tempelaar, D. T., \& Nijhuis, J. (2007). Commonalities in attitudes and beliefs toward different academic subjects. In M. K. McCuddy, H. Van der Bosch, J. W. B. Martz, A. V. Matveev \& K. O. Morse (Eds.), Educational innovation in economics and business $X$ : The challenges of educating people to lead in a challenging world (pp. 225-250). Berlin: Springer.

Tempelaar, D. T., \& Schim van der Loeff, S. (2011, August). The development of students' subject attitudes when taking a statistics course. Paper presented at 58th World Statistics Congress of the International Statistical Institute, Dublin, Ireland.

Tempelaar, D. T., Schim van der Loeff, S., \& Gijselaers, W. H. (2007). A structural equation model analyzing the relationship of students' attitudes toward statistics, prior reasoning abilities, and course performance. Statistics Education Research Journal, 6(2), 78-102.

[Online: http://www.stat.auckland.ac.nz/ iase/serj/SERJ6\%282\%29 Tempelaar.pdf]

Tempelaar, D. T., Schim van der Loeff, S., Gijselaers, W. H., \& Nijhuis, J. F. H. (2011). On subject variations in achievement motivations: A study in business subjects. Research in Higher Education, 52(4), 395-419.

Usher, E. L., \& Pajares, F. (2008). Sources of self-efficacy in school: Critical review of the literature and future directions. Review of Educational Research, 78(4), 751-796.

Verhoeven, P. S. (2009). Quality in statistics education determinants of student outcomes in methods \& statistics education at universities and colleges (Unpublished doctoral dissertation). Amsterdam: Boom Onderwijs.

Verhoeven, P. S. (2011, August). Attitudes toward statistics: The effort of learning. Paper presented at the 58th World Statistics Congress of the International Statistical Institute, Dublin, Ireland.

Waters, L. K., Martelli, T. A., Zakrajsek, T., \& Popovich, P. M. (1988). Attitudes toward statistics: An evaluation of multiple measures. Educational and Psychological Measurement, 48(2),513516.

Watson, F. S., Lang, T. R., \& Kromrey, J. D. (2002, November). Breaking ground for EncStat: A statistics anxiety intervention program. Paper presented at the annual meeting of the Florida Educational Research Association, Gainesville, FL.

Watson, F. S., Lang, T. R., Kromrey, J. D., Ferron, J. M., Hess, M. R., Hogarty, K.Y. (2003, April). An assessment blueprint for EncStat: A statistics anixety intervention program. Paper presented at the annual meeting of the American Educational Research Association, Chicago.

Watt, H. M. G. (2005). Explaining gendered math enrolments for NSW Australian secondary school students. New Directions for Child and Adolescent Development, 110(Winter), 15-29.

Wentzel, K. R., \& Wigfield, A. (2009). Handbook of motivation at school. New York: Routledge. 
Wigfield, A., \& Eccles, J. S. (2000). Expectancy-value theory of achievement motivation. Contemporary Educational Psychology, 25(1), 68-81.

Wigfield, A., \& Eccles, J. S. (2002). The development of competence beliefs, expectancies for success, and achievement values from childhood through adolescence. In A. W. J. S. Eccles (Ed.), Development of achievement motivation. San Diego, CA: Academic Press.

Wigfield, A., \& Tonks, S. (2002). Adolescents' expectancies for success and achievement task values during the middle and high school years. In F. Pajares \& T. Urdan, Academic motivation of adolescents (pp. 53-82). Greenwich, CT: Information Age Publishing.

Wise, S. L. (1985). The development and validation of a scale measuring attitudes toward statistics. Educational and Psychological Measurement, 45(2), 401-405.

Wisenbaker, J. M., Scott, J. S., \& Nasser, F. (1999, August). A cross-cultural comparison of path models relating attitudes about and achievement in introductory statistics courses. Paper presented at the International Statistical Institute, 52nd Session, Helsinki.

Zanakis, S. H., \& Valenzi, E. R. (1997). Student anxiety and attitudes in business statistics. Journal of Education for Business, 73(1), 10-16.

Zeidner, M. (1991). Statistics and mathematics anxiety in social science students: Some interesting parallels. British Journal of Educational Psychology, 61(3), 319-328.

CAROLINE RAMIREZ

University of the Pacific

Department of Mathematics

3601 Pacific Ave.

Stockton, CA 95211 